\title{
An Approach to Integrating Historical Perspective into an Undergraduate Accounting Course
}

\author{
Ron Baker ${ }^{1}$ (D) \\ ${ }^{1}$ Assoc. Prof., University of Guelph, Ontario, Canada \\ ORCID: R.B. 0000-0003-2464-7231
}

\begin{abstract}
This paper describes an approach to integrating historical perspective into a fourth-year accounting course to supplement student learning of contemporary issues in accounting. Historical materials were mapped onto the course curriculum and delivered either through additional reading assignments or lectures. The purpose of this paper is to present an approach to course design that integrates an historical perspective into a course in an active manner. It provides a pathway for the inclusion of accounting's history and accounting history research into accounting education. This approach goes beyond providing students with an abstract list of suggested readings. Instead, it incorporates supplemental material through two mapping processes: by topic and by course. This represents a novel and thorough approach to introducing an historical perspective of accounting to students while at the same time providing opportunities for examining contemporary accounting issues in a deeper and more robust way.
\end{abstract}

Keywords: Accounting education, accounting history, pedagogy

Submitted/Başvuru: 24.08.2020 Revision Requested/Revizyon Talebi: 19.11.2020 Last Revision Received/Son Revizyon: 11.12.2020 Accepted/Kabul: 18.01.2020 Corresponding author/Sorumlu yazar: Ron Baker/ron@uoguelph.ca

Citation/Atıf: Baker, R. (2021). An approach to integrating historical perspective into an undergraduate accounting course. Muhasebe Enstitüsü Dergisi - Journal of Accounting Institute, 64, 85-91. https://doi.org/10.26650/MED.784978 


\section{Introduction}

There is a long tradition of accounting education being subject to criticism (Fogarty, 2010). The approach that has been adopted in undergraduate accounting programs, with its focus on developing technical accounting skills (Kimmel, 1995; Demski, 2007; Parker et al., 2011; Gendron, 2015) has been described as being too narrow and fails to develop important skills and competencies such as critical thinking and life-long learning (Webb and Chaffer, 2016; Parker et al., 2011; Diamond, 2005; Burnett, 2003; Albrecht and Sack, 2000). The focus on practice informing the curriculum has led to a somewhat closed system that impedes the development of new accounting thought, practices and ideas (Inanga and Schneider, 2005; Sterling, 1973) to the detriment of developing intellectual skills (Douglas and Gammie, 2019). This firstjob focus and technical competency approach (Demski, 2007) may be a factor in the diminishing interest of students as they progress through their undergraduate program (Marriott and Marriott, 2003; Albrecht and Sack, 2001). Yet accounting education reform, when it does occur, seems to do so only at the fringes (Dellaportas, 2019).

There has also been a long tradition of calls for incorporating history into business education and into accounting programs (Flegm, 1991; Zeff, 1989; AAA, 1986). It has been argued that instilling in students a sense of the importance and relevance of an historical perspective of accounting will result in more critically aware and well-rounded accounting practitioners (Bisman, 2009). Accounting's history provides a perspective beyond its technical aspects, raising awareness of it as a product of cultural, political and economic forces (Richardson, 2008; Albin, 1994). Current accounting practices and understandings of these practices will be richer and better explained in the context of accounting's history (Previts et al., 1990). Amernic and Craig (2004) point out, for example, that the reforms arising from the Enron fallout had been suggested and ignored by accountants for decades. This historical perspective changes the narrative about accounting "failure" from that of a new phenomenon, a new "fire" to put out (see Sterling, 1967) to one of the accounting profession itself - its development or lack thereof and the systems and structures associated with it. The literature on accounting education reforms involving this historical perspective, however, is scant (Apostolou, et al., 2013).

This paper describes a case of integrating an historical perspective ( $20^{\text {th }}$ century history) into a course in an effort to enhance student understanding of several accounting topics. While accounting history and/or accounting history research could have been incorporated into the course as a distinct topic, this approach was not taken. Rather, academic articles providing an historical perspective on an accounting topic were used, along with lectures, to encourage a broader perspective on that topic. This approach adopts the perspective of integrating the material into the curriculum as a pedagogical tool rather than as solely subject matter (see Coffman et al., 1989). While the use of supplemental instruction has been studied (see, for example, Etter et al., 2000; Jones and Fields, 2001; Goldstein et al., 2014), the integration of supplemental material is not well represented in the literature.

\section{Course Description}

A fourth-year course entitled Accounting Theory was selected for the integration of the historical perspective material. This course runs for a 12-week semester consisting of 24 in-class sessions held twice a week. Students take this course in the final semester of their four-year undergraduate program. It was re-designed in 2015 from a more traditional theory course using Scott's Financial Accounting Theory as a cornerstone textbook (Scott, 2012) to a course examining an array of accounting topics. The new design was informed by two discourses: the call for innovations in accounting education that promote deep rather superficial learning approaches and the role of research in accounting's claim to be an academic discipline (Baker and Wick, 2019). Critically reading and commenting on accounting research became the core of the redesigned course. The topics covered include measurement, the conceptual framework, accounting education, sustainability, earnings management, fair value accounting, corporate failure and corporate governance. Students were also introduced to a number of theories commonly used in accounting research: agency, institutional theory, stakeholder theory, contingency, and legitimacy theory. Students used a textbook, Contemporary Issues in Accounting (Rankin et al., 2012), and read academic accounting research articles from peer-reviewed journals. Assessments consisted of exams and written assignments critiquing assigned journal articles. 


\section{Integrating History}

A mapping exercise was undertaken to identify historical articles and material that could supplement the learning of a particular topic (see Appendix 1). Not all topics were specifically selected for this exercise primarily due to time constraints. Two related topics that received particular attention however were the conceptual framework and theories in accounting. As an example, a description of the learning approach for the conceptual framework topic follows.

The textbook includes a chapter devoted to the conceptual framework. In this chapter a description of the framework (i.e. the users, elements, qualitative characteristics, etc.) and a brief history of its development are provided. The primary academic article assigned to this topic is the critical perspective of the conceptual framework authored by Hines (1989). This article provides students with four streams of thought and discussion: a history of the development of the profession, a history of the development of the conceptual framework, a critical interpretation of these developments and an introduction to research using historical data. Thus the importance of the history of the topic is integrated into one's understanding of the development of the framework.

This material was supplemented with a lecture on the development of the framework in the Canadian context. But the historical account provided in class was not limited to the framework. Rather, a second article by Sterling (1967) was assigned and used to provide the background on how accounting came to be developed. This was supplemented with a lecture summarizing Zeff's account of the formalization of accounting in the U.S. (Zeff, 1999). Through this topic, therefore, students came to understand the nature of accounting's inductive development and the importance of this history with respect to how accounting continues to develop and change ${ }^{1}$. Students were required to write a three-page critique of the Hines article; this promoted engagement with the article and the supplementary material. Finally, an in-class reflection exercise was undertaken to draw attention to the role of an accounting topic's history and accounting's history as context for informing an understanding of the topic (Appendix 2). For this exercise students were provided with a short list of questions regarding the role of a topic's history in informing their understanding of the topic. They were given an opportunity to write their responses down and then each question was discussed in class. Figure 1 maps the process followed for the topic.

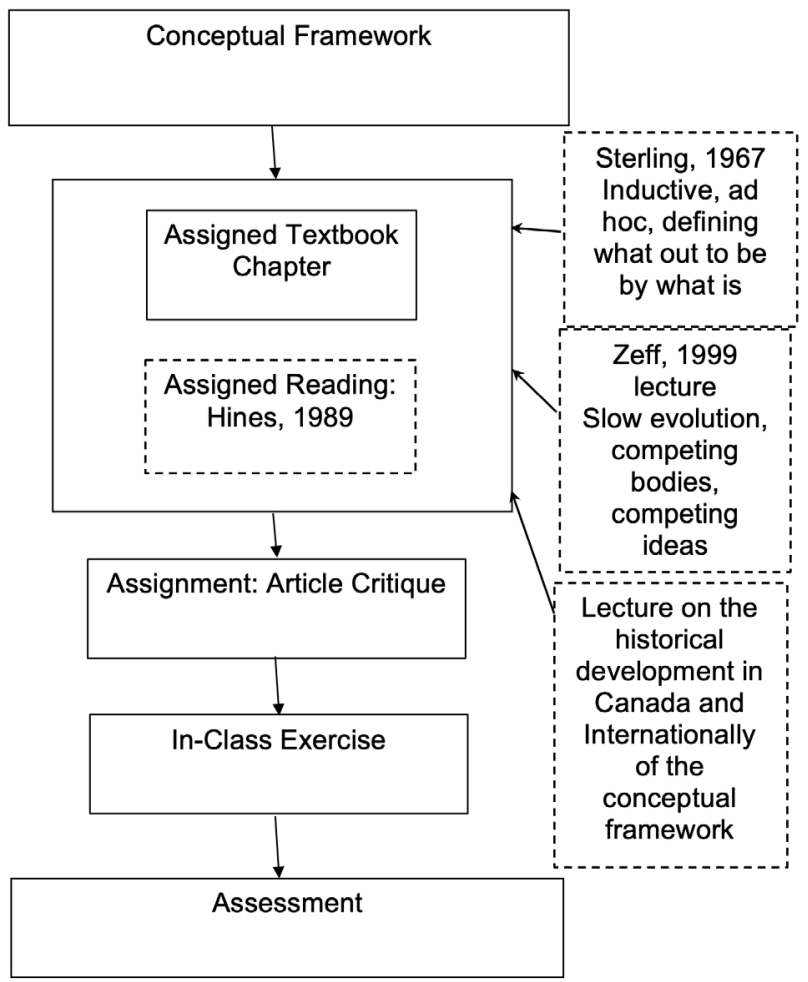

Figure 1. Topic Mapping - Conceptual Framework

1 Contingency theory was also introduced as a theoretical lens through which an interpretation of accounting's history might be developed; a demonstration of the usefulness of theory. 
Note that the dashed line boxes represent the material with historical content used to inform the understanding of the topic.

The process begins with the identification of the topic. Assigned readings (the textbook and the assigned article) are the core learning activities. Class discussion was supplemented by an additional article and the class lecture. Student activities, the critique and the in-class exercise, were used to engage the students in active learning. Finally, an assessment, in the form of exam questions, was undertaken. Importantly, students were encouraged to use this supplementary material to draft their responses to the exam questions and marks were assigned for doing so.

\section{Instructor Impressions}

This approach was first adopted for the Winter 2020 semester iteration of the course. As such, only preliminary anecdotal impressions can be offered here. With respect to the usefulness of the historical material, student reaction was very positive. With one notable exception, a student who felt that looking at the past did not help, the majority of students expressed that the historical perspective was interesting and useful. In the case of fair value accounting, for example, many students did not realize that this form of accounting had been debated for decades - many assumed it was a relatively new "innovation". This perspective caused them to be a little more critical about current practices and standards rather than accepting that they are "better" than previous practices and standards. It also seemed to encourage some students to consider how standards came to be developed and why we have the standards that we do now.

Thus, integrating the historical perspective to each accounting topic seemed to promote a deeper, critical and more thoughtful approach to understanding current issues in accounting. The students who responded well to this approach became interested in viewing current accounting practices in the context of their historical development. They sought an understanding of the rationale behind accounting practices and moved away from simply accepting them at face value. Further study needs to take place. The impressions presented here are subject to limitations. A multi-year study with a formal student feedback instrument will better our understanding of the usefulness of this approach. Nevertheless, in this instance, students, by and large, were interested in the historical perspective. They found accounting's history to be useful for understanding today's practices and standards and they seemed to develop a more critical approach to learning the material.

\section{Conclusion}

This paper describes an application of integrating historical perspective into an undergraduate accounting course. While calls for an historical perspective of accounting to be incorporated into the curriculum have been persistent, few attempts have been made to do this. There are exceptions (i.e. Sangster et al., 2014; 2007), but these are few. The approach adopted here is to integrate an historical perspective to an accounting topic and the history of the development of modern accounting more broadly speaking as contextual information. Preliminary (and informal) results suggest that the approach has been well-received and that this historical information has been interesting and useful. It appears to promote interest in accounting history research, change the perspectives of students about accounting and encourage a more thoughtful and critical approach to learning. Further study, however, is required.

Gomes et al. (2011) ask "Does accounting history matter?". The purpose of this study is to determine if an historical perspective of accounting matters to undergraduate accounting students. It appears that it does. Furthermore, this paper presents a way in which an historical perspective of accounting can be employed in the classroom to develop a deeper and more thoughtful understanding of accounting topics.

Peer-review: Externally peer-reviewed.

Conflict of Interest: The author has no conflict of interest to declare.

Grant Support: The author declared that this study has received no financial support.

Hakem Değerlendirmesi: Dış bağımsız.

Çıkar Çatışması: Yazar çıkar çatışması bildirmemiştir.

Finansal Destek: Yazar bu çalıșma için finansal destek almadığını beyan etmiștir. 


\section{References}

Albin, M. (1994). A cross cultural look at the origins and development of accounting. Accounting Educator's Journal 6: 110-127.

Albrecht, W.S. and Sack, R.J. (2000). Accounting education: Charting the course through a perilous future. Sarasota, FL: American Accounting Association

Albrecht, W.S. and Sack, R.J. (2001). The perilous future of accounting education. The CPA Journal 71 (3): 16-23.

American Accounting Association (AAA) (1986). Special report: Future accounting education: Preparing for the expanding profession. Issues in Accounting Education, 1(1), 168-195.

Amernic, J. and Elitzur, R. (1992). Using historical annual reports in teaching: Letting the past benefit the present. Accounting Historians Journal, 19(1), 29-50.

Amernic, J. and Craig, R. (2004). Reform of accounting education in the post- Enron era: Moving accounting 'out of the shadows. Abacus, $40(3), 342-378$

Apostolou, B., Dorminey, J. W., Hassell, J. M., and Watson, S. F. (2013). Accounting education literature review (2010-2012). Journal of Accounting Education, 31(2), 107-161.

Baker, R., and Wick, S. (2019). A Narrative on integrating research and theory into undergraduate accounting curriculum. Meditari Accountancy Research, 27(2), 325-344.

Bisman, J. (2009). Making accounting historians. Accounting Historians Journal, 36(1), 135-162.

Coffman, E. N., Roberts, A. R., and Previts, G. J. (1989). A history of the academy of accounting historians 1973-1988. Accounting Historians Journal, 16(2), 155-206.

Dellaportas, S. (2019). Accounting education what it is, and what it is not. Accounting Education, 28(2), 119-126.

Demski, J. S. (2007). Is accounting an academic discipline?, Accounting Horizons, 21(2), 153-157.

Diamond, M. (2005). Accounting education, research and practice: After Enron, where do we go?. European Accounting Review, 14(2), $353-362$.

Douglas, S., and Gammie, E. (2019). An investigation into the development of non-technical skills by undergraduate accounting programmes. Accounting Education, 28(3), 304-332.

Etter, E. R., Burmeister, S. L., \& Elder, R. J. (2000). Improving student performance and retention via supplemental instruction. Journal of Accounting Education, 18(4), 355-368.

Flegm, E. H. (1991). The relevance of history in accounting education: Some observations. Journal of Accounting Education, 9(2), 355-363.

Fogarty, T. J. (2010). Revitalizing accounting education: A highly applied liberal arts approach. Accounting Education: an international journal, 19(4), 403-419.

Gendron, Y. (2015). Accounting academia and the threat of the paying-off mentality. Critical Perspectives on Accounting, 26, $168-176$.

Goldstein, J., Sauer, P., \& O’Donnell, J. (2014). Understanding factors leading to participation in supplemental instruction programs in introductory accounting courses. Accounting Education, 23(6), 507-526.

Gomes, D., Carnegie, G. D., Napier, C. J., Parker, L. D., and West, B. (2011). Does accounting history matter? Accounting History, 16(4), $389-402$.

Hines, R. D. (1989). Financial accounting knowledge, conceptual framework projects and the social construction of the accounting profession. Accounting, Auditing \& Accountability Journal, 2(2), 72-92.

Inanga, E. L. and Schneider, W. B. (2005). The failure of accounting research to improve accounting practice: a problem of theory and lack of communication. Critical Perspectives on Accounting, 16(3), 227-248.

Jones, J. P., \& Fields, K. T. (2001). The role of supplemental instruction in the first accounting course. Issues in Accounting Education, 16(4), 531-547.

Kimmel, P. (1995). A framework for incorporating critical thinking into accounting education. Journal of Accounting Education, 13(3), 299-318. 
Parker, L.D., Guthrie, J., and Linacre, S. (2011). The relationship between academic accounting research and professional practice. Accounting, Auditing \& Accountability Journal, 24(1), 5-14.

Previts, G. J., Parker, L. D., and Coffman, E. N. (1990). Accounting history: definition and relevance. Abacus, 26(1), 1-16.

Rankin, M., Stanton, P., McGowan, Ferlauto, K., and Tilling, M. (2012). Contemporary Issues in Accounting. Australia: Wiley and Sons. Richardson, A. J. (2008). Strategies in the development of accounting history as an academic discipline. Accounting History, 13(3), $247-280$.

Sangster, A., Stoner, G. N., and McCarthy, P. A. (2007). Lessons for the classroom from Luca Pacioli. Issues in Accounting Education, 22(3), 447-457.

Sangster, A. (2010). Using accounting history and Luca Pacioli to put relevance back into the teaching of double entry. Accounting, Business \& Financial History, 20(1), 23-39.

Sangster, A., Franklin, E., Alwis, D., Abdul-Rahim, J., and Stoner, G. (2014). Using Pacioli’s pedagogy and medieval text in today's introductory accounting course. Journal of Accounting Education, 32(1), 16-35.

Scott, WR (2012). Financial Accounting Theory, $6^{\text {th }}$ Edition. Toronto: Pearson Canada Inc.

Sterling, R.R. (1967). A statement of basic accounting theory: A review article. Journal of Accounting Research, 5(1), 95-112.

Sterling, R.R. (1973). Accounting research, education and practice. Journal of Accountancy (pre-1986), 136(3), 44-52.

Webb, J., \& Chaffer, C. (2016). The expectation performance gap in accounting education: A review of generic skills development in UK accounting degrees. Accounting Education, 25(4), 349-367.

Zeff, S. A. (1989). Does accounting belong in the university curriculum. Issues in Accounting Education, 4(1), $203-210$.

Zeff, S. A. (1999). The evolution of the conceptual framework for business enterprises in the United States. Accounting Historians Journal, 26(2), 89-131. 
Appendix 1

Course Mapping

\begin{tabular}{|c|c|c|c|}
\hline Topic & Assigned Readings & Historical Supplement & Reference \\
\hline Accounting Education & $\begin{array}{l}\text { Textbook Chapter 1; } \\
\text { Baker and Wick, 2019; } \\
\text { Baker } 2011\end{array}$ & History of Accounting Education & Chu and Man, 2012 \\
\hline Conceptual Framework & $\begin{array}{l}\text { Textbook Chapter 2; } \\
\text { Hines, } 1989\end{array}$ & $\begin{array}{l}\text { The evolution of the conceptual framework for } \\
\text { business enterprises in the United States }\end{array}$ & Zeff, 1999 \\
\hline Measurement & $\begin{array}{l}\text { Textbook Chapter 4; } \\
\text { Sunder, } 2015\end{array}$ & & \\
\hline Theories in accounting & $\begin{array}{l}\text { Textbook Chapter 5; } \\
\text { Sterling, 1967; Inanga and } \\
\text { Schneider, } 2005\end{array}$ & Accounting theory: missing in action? & Cluskey Jr et al., 2007 \\
\hline $\begin{array}{l}\text { Products of financial } \\
\text { reporting }\end{array}$ & $\begin{array}{l}\text { Textbook Chapter 6; } \\
\text { Watts and Zimmerman, } 1978\end{array}$ & $\begin{array}{l}\text { Alvin R. Jennings: Managing partner, policy- } \\
\text { maker, and institute president. }\end{array}$ & Persson et al., 2015 \\
\hline Corporate Governance & $\begin{array}{l}\text { Textbook Chapter 7; } \\
\text { Baker et al., } 2012 \\
\end{array}$ & & \\
\hline Capital markets research & Textbook Chapter 8 & $\begin{array}{l}\text { Presentation based on: Roberts, A. L. "The Role } \\
\text { of Accounting In The Stock Market Crash of } \\
\text { 1929, Research Monograph No. 96.” (1985): } \\
\text { 133-136. } 1929 \text { Stock Market Crash and the Great } \\
\text { Depression - Documentary Youtube: https:// } \\
\text { www.youtube.com/watch?v=qlSxPouPCIM. } \\
\text { Wither Accounting Research? }\end{array}$ & Hopwood, 2007 \\
\hline Earnings Management & $\begin{array}{l}\text { Textbook Chapter 9; } \\
\text { Dechow and Skinner, } 2000\end{array}$ & & \\
\hline Fair Value accounting & $\begin{array}{l}\text { Textbook Chapter 10; } \\
\text { Laux and Leuz } 2009\end{array}$ & $\begin{array}{l}\text { In pursuit of legitimacy: A history behind fair } \\
\text { value accounting }\end{array}$ & $\begin{array}{l}\text { Georgiou and Jack, } \\
2011\end{array}$ \\
\hline Sustainability & $\begin{array}{l}\text { Textbook Chapter 11; } \\
\text { Mäkelä et al, 2017; Egan } \\
\text { and Tweedie, } 2018\end{array}$ & $\begin{array}{l}\text { Sustainability accounting - a brief history and } \\
\text { conceptual framework }\end{array}$ & Lamberton, 2005 \\
\hline Corporate failure & $\begin{array}{l}\text { Textbook Chapter 12; } \\
\text { Baker and Hayes, } 2004\end{array}$ & $\begin{array}{l}\text { Teaching the accountant the history and ethics of } \\
\text { his profession }\end{array}$ & Myer, 1931 \\
\hline
\end{tabular}

\section{Appendix 2}

\section{In Class Exercise}

In-Class Exercise: The Conceptual Framework

1. How has accounting been developed?

2. How has the conceptual framework been developed?

3. Is the development of the conceptual framework related to the development of accounting in general?

4. How has your understanding of the development of accounting shaped your understanding of the accounting system we have today?

5. Does this history matter? In what ways? 
